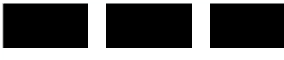 \\ m
}

THE WiLliam DAVIDSON INSTITUTE

AT THE UNIVERSITY OF MICHIGAN BUSINESS SCHOOL

\section{How to Catch Foreign Fish? FDI and Privatization in EU Accession Countries}

\author{
By: Bruno Merlevede and Koen Schoors
}

William Davidson Institute Working Paper Number 785

August 2005 


\title{
How to Catch Foreign Fish? FDI and Privatisation in EU Accession Countries
}

\author{
Bruno Merlevede* \\ Departmen of Economics and CERISE, Ghent University \\ Koen Schoors \\ Departmen of Economics and CERISE, Ghent University, \\ and WDI
}

August 10, 2005

\begin{abstract}
We examine the determinants of FDI stocks of 'old' EU-members in ten accession countries. Our partial adjustment framework results in a dynamic panel data analysis. In addition to the traditional variables, such as market potential and unit labour costs, we find institutional development to be a robust determinant of equilibrium FDI stocks. The adjustment towards equilibrium is rapid. The relationship between FDI and the privatization process is complex. Non-direct privatization schemes negatively affect the speed of adjustment, whereas direct privatization strategies positively affect the equilibrium itself. Privatization history increases equilibrium FDI stocks, independently of the method applied.
\end{abstract}

JEL Classification: F20, F23, P33

Keywords: foreign direct investment, privatisation, partial adjustment

*Corresponding author: CERISE - Centre for Russian International and Socio-Political and Economic Studies, Ghent University, Hoveniersberg 24, B-9000 Ghent, Belgium; tel.: +32-9-264.35.03; fax: +32-9264.35.99; bruno.merlevede@ugent.be 


\section{Introduction}

Attracting FDI is high on the priority list of many policymakers because FDI is widely regarded as an amalgamation of capital, technology, marketing, and managerial practices, especially in developing economies. Policymakers therefore have a genuine interest to know what attracts FDI. From a theoretical point of view it is necessary to identify the conditions under which foreign investment will take place, because of the costs inherent to entering new markets and producing abroad (Markusen, 1995). Although considerable work has been done, there is no consensus model providing the basis for empirical work. The questions and the analytical approaches to answer them are drawn from different subfields of economic theory. Some approaches stem from the larger field of macroeconomics, some relate to general equilibrium trade theory, and some are more closely related to the theory of the firm (see Markusen and Maskus, 2001). The macro-approach, followed here, typically consists in estimating the effect of potential determinants of FDI by regressing some transformation of FDI on a set of independent variables which on theoretical grounds would likely affect the profitability of investment. These variables reflect or affect the local market potential, the cost of production, and the general business environment. We further add institutional development to the list of potential determinants and test whether good institutions add to the attractiveness of a potential host country.

We examine the determinants of foreign direct investment into the countries of Central and Eastern Europe (CEECs) by EU member states. Prior to 1990 the scope for FDI was extremely limited in Central and Eastern Europe. The sudden collapse of the central planning system opened these countries to foreign investment resulting in a continuous flow of investment to the CEECs. The considerable variation in the nature and the speed of institutional development during the transition process makes the CEECs perfectly suited to study the impact of institutional change on foreign investment. Especially the organization of the privatization process of formerly state-owned enterprises deserves a closer look, for it has been explicitly used as an element in strategies to attract or prevent FDI. Hungary, for example, encouraged foreign involvement in the privatization process by tailoring privatization schemes to foreigners. Prospective EU membership and integration in the EU are another 'institution' that could be an important determinant of FDI in transition countries. Indeed, Baldwin et al. (1997) attribute the bulk of the gain from EU membership to increased investment, coming from both reduced domestic risk and increased FDI flows.

Given the state of economic and institutional development, there exists an equilibrium level of foreign penetration in an economy. We think of FDI flows as an adjustment process towards an equilibrium level of the FDI stock. The observed FDI stock is then the result of 
two forces. On the one hand the stock will be evolving towards an equilibrium level even without policy changes or changes in other determinants. On the other hand the equilibrium level itself is continuously altered by changes in its determinants. We specify a partial stock adjustment model that nicely reflects the main features of the process of FDI flows into the accession countries, namely i) the FDI stock was initially approximately zero and gradually adjusts towards its equilibrium, ii) investment flows depend on the actual stock, and iii) the equilibrium stock itself changes with the state of economic and institutional development. To date the empirical literature has largely ignored the dynamic aspects of the FDI process

in transition countries. Kinoshita and Campos (2003) and Carstensen and Toubal (2004) are the exceptions. Kinoshita and Campos (2003) analyse FDI inflows at the country level which results in a more limited number of cross-section elements. Carstensen and Toubal (2004) also consider bilateral flows from the EU to the candidate countries. We differ from their analysis by developing a partial adjustment model into a dynamic panel setup where we eventually allow the speed of adjustment to the equilibrium to be influenced by the choice of the privatization strategy.

The structure of the paper is as follows. Section 2 lays out some stylized facts of FDI, the transition process, and the investment flows from the EU to Central and Eastern Europe. Section 3 develops a partial adjustment model of FDI and introduces the determinants of the equilibrium FDI stock. The data and estimation procedure are discussed in section 4, while section 5 contains the results. Section 6 concludes.

\section{FDI and transition}

Already early in transition it became clear that most of the CEECs were redirecting their economy towards Western Europe. Their increasing integration with the EU resulted in a stream of FDI inflows from the EU. This stream reflects a continuous adjustment towards a desired equilibrium FDI stock by EU-countries in these newly emerging economies that since the start of transition have been expected to join the EU sooner or later. Table 1 shows inward FDI stocks in nine CEECs from EU countries and the US. ${ }^{1}$ The EU accounts for about $80 \%$ of the stock of inward investment in most countries. The exceptions are Bulgaria, Latvia and Lithuania. For Bulgaria, other important source countries -apart from the US in the last line of table 1- are Cyprus (9.6\%), Russia (6.7\%), Switzerland (3.8\%) and the Bahamas (3.7\%). For Latvia, the other important sources are Estonia and Russia $(11.2 \%$ and 6.0\% respectively). In the case of Lithuania, FDI is spread out more equally. Switzerland, Norway,

\footnotetext{
${ }^{1}$ There were no data available for Romania.
} 


\begin{tabular}{|c|c|c|c|c|c|c|c|c|c|}
\hline Source & $\begin{array}{c}\text { Bulgaria } \\
1999 \\
\end{array}$ & $\begin{array}{c}\text { Czech } \\
\text { Republic } \\
2000 \\
\end{array}$ & $\begin{array}{c}\text { Estonia } \\
2001 \\
\end{array}$ & $\begin{array}{c}\text { Hungary } \\
2000 \\
\end{array}$ & $\begin{array}{r}\text { Latvia } \\
2000 \\
\end{array}$ & $\begin{array}{c}\text { Lithuania } \\
2000 \\
\end{array}$ & $\begin{array}{c}\text { Poland } \\
2000 \\
\end{array}$ & $\begin{array}{c}\text { Slovakia } \\
2000 \\
\end{array}$ & $\begin{array}{c}\text { Slovenia } \\
2000 \\
\end{array}$ \\
\hline Austria & 5.6 & 11.1 & 0.2 & 12.2 & 0.5 & 0.7 & 3.3 & 14.5 & 45.6 \\
\hline Belgium & 6.2 & 5.4 & 0.3 & 5.3 & - & 4.1 & 2.5 & 1.6 & 1.3 \\
\hline Denmark & 0.1 & 1.2 & 3.4 & 0.5 & 10.5 & 18.3 & 2.5 & - & 1.5 \\
\hline Finland & - & 0.6 & 25.4 & 1.6 & 6.2 & 6.0 & 0.6 & - & - \\
\hline France & 2.7 & 4.3 & 0.9 & 6.5 & - & 1.1 & 12.5 & 3.2 & 10.7 \\
\hline Germany & 19.3 & 25.5 & 2.6 & 25.8 & 11.1 & 7.4 & 19.0 & 28.7 & 12.5 \\
\hline Italy & 1.7 & 0.8 & 0.6 & 2.7 & 0.1 & 0.2 & 4.4 & 1.5 & 5.4 \\
\hline Netherlands & 3.7 & 30.1 & 4.0 & 22.5 & 2.8 & 1.1 & 26.1 & 24.4 & 3.0 \\
\hline Portugal & 0.1 & - & - & 0.1 & - & 0.1 & 0.5 & - & - \\
\hline Spain & 2.6 & 0.2 & - & 0.4 & 0.1 & - & 1.9 & - & - \\
\hline Sweden & 0.3 & 1.4 & 39.5 & 0.9 & 12.6 & 17.3 & 3.5 & - & 0.5 \\
\hline UK & 11.0 & 4.8 & 3.2 & 1.1 & 5.0 & 6.7 & 3.3 & 3.2 & 3.6 \\
\hline Sum & 53.3 & 85.4 & 80.1 & 79.6 & 48.9 & 63.0 & 80.1 & 77.1 & 84.1 \\
\hline US & 12.0 & 6.5 & 9.5 & 8.2 & 9.4 & 9.8 & 9.6 & 6.8 & 3.9 \\
\hline
\end{tabular}

Table 1: Percentage of inward FDI stock in transtion countries originating from 12 EUcountries and the US

\begin{tabular}{|c|c|c|c|c|c|c|c|}
\hline & $\begin{array}{c}(1) \\
\text { FDI stock }\end{array}$ & $\begin{array}{c}(2) \\
\text { FDI stock } \\
\text { per capita }\end{array}$ & $\begin{array}{c}(3) \\
\text { GDP } \\
\text { per capita }\end{array}$ & $\begin{array}{c}(4) \\
\text { Monthly } \\
\text { gross } \\
\text { wage }\end{array}$ & $\begin{array}{c}5) \\
\text { Private } \\
\text { sector } \\
\text { share } \\
\end{array}$ & $\begin{array}{c}(6) \\
\text { Country } \\
\text { risk }\end{array}$ & $\begin{array}{c}(7) \\
\text { Transition } \\
\text { index }\end{array}$ \\
\hline Czech Republic & 21644 & 2107 & 5423 & 342 & 80 & 61.67 & 3.3 \\
\hline Hungary & 19804 & 1987 & 4636 & 319 & 80 & 63.54 & 3.6 \\
\hline Poland & 34227 & 870 & 4300 & 347 & 70 & 62.63 & 3.4 \\
\hline Slovakia & 4634 & 858 & 3752 & 246 & 80 & 50.70 & 3.1 \\
\hline Slovenia & 2809 & 1413 & 9534 & 710 & 65 & 70.11 & 3.2 \\
\hline Estonia & 2645 & 1898 & 3761 & 302 & 75 & 55.02 & 3.3 \\
\hline Latvia & 2084 & 860 & 3250 & 236 & 65 & 52.60 & 2.9 \\
\hline Lithuania & 2334 & 632 & 3252 & 252 & 70 & 50.45 & 3.1 \\
\hline Bulgaria & 2716 & 398 & 1547 & 125 & 70 & 41.13 & 2.8 \\
\hline Romania & 6480 & 290 & 1649 & 130 & 60 & 35.21 & 2.7 \\
\hline
\end{tabular}

Table 2: Overview of macroeconomic situation in 10 Central and Eastern European Countries

and Estonia are the larger source countries, all three accounting for about $5 \%$ of the inward FDI stock. Overall Germany is the most important investor in Central and Eastern Europe. The Netherlands are at least an equally important source of investment for four advanced transition countries (Czech Republic, Hungary, Poland, and Slovak Republic), but only play a minor role in the other countries. Austria is an important investor in its neighbouring countries. The Baltic States are strongly linked with Scandinavian countries. Denmark, Finland and Sweden account for nearly $70 \%$ of the FDI stock in Estonia, $30 \%$ in Latvia, and $42 \%$ in Lithuania.

Table 2 presents macroeconomic figures for the year 2000 for the countries in our analysis. Poland has the largest inward FDI stock, followed by the Czech Republic and Hungary. The other countries are far behind in absolute figures. Looking at per capita figures the ranking 
changes. The Czech Republic and Hungary are still on top of the list, but Poland drops to fifth place, only just in front of Latvia and the Slovak Republic. Eyeballing columns 2 and 3 suggests a positive relation between income and per capita FDI stocks, lending some credibility to the market seeking hypothesis. The FDI per capita figures further reveal that Bulgaria and Romania are the worst performers. This can also be related to the other columns in table 2: both countries are perceived as more risky than the others (see column 6 , a higher score means a less risky country), and their transition index has fallen behind (column 7), which is also reflected by the somewhat smaller share of the private sector in GDP (column 5). This is a first indication that institutional development might be important to attract FDI. On the other hand, average gross monthly wages are much lower in Bulgaria and Romania (see column 4). Ceteris paribus, this should help them to attract more FDI, unless the lower wage levels correspond to lower productivity levels. Finally, note that Slovenian wages are very high compared to the other countries.

\section{A partial stock adjustment model}

Given the state of development of the economy, there is an equilibrium level of foreign investment, FDI*. We think of FDI flows as an adjustment process of the FDI stock towards this equilibrium. This can be captured in a partial stock adjustment framework where $i$ ) the rate of growth of FDI is - ceteris paribus- proportional to the stock of FDI and ii) the rate of growth is -ceteris paribus- proportional to the equilibrium value, $F D I^{*}$. The law of growth of FDI can be written as:

$$
\frac{d F D I}{d t}=\kappa F D I\left(F D I^{*}-F D I\right) \quad 0<\kappa<1
$$

Some rewriting shows that the percentage rate of growth is a linear decreasing function of FDI:

$$
\frac{d F D I}{F D I d t}=\frac{d \ln F D I}{d t}=\kappa\left(F D I^{*}-F D I\right)
$$

Cheng and Kwan (2000) suggests the analytically more convenient expression:

$$
\begin{aligned}
\frac{d \ln F D I_{i, t}}{d t} & =\alpha\left(\ln F D I_{i, t}^{*}-\ln F D I_{i, t-1}\right) \quad 0<\alpha<1 \\
& \Leftrightarrow \frac{d F D I_{i, t}}{d t}=\alpha F D I_{i, t}\left(\ln F D I_{i, t}^{*}-\ln F D I_{i, t-1}\right)
\end{aligned}
$$

Note that the equilibrium level of FDI also gets a time indicator because its determi- 
nants vary over time. This is distinctively the case in the countries considered because of the institutional change inherent to the transition process. (3) says that the percentage change of the FDI stock is proportional to the gap between $\ln F D I_{i, t}^{*}$ and $\ln F D I_{i, t-1}$. Since $d \ln F D I_{i, t}=d F D I_{i, t} / F D I_{i, t}$, we can infer from (4) that the rate of change of the FDI stock is proportional to the existing stock, holding the gap constant. Here we assume that the equilibrium level, $F D I_{i, t}^{*}$, is unaffected by $F D I_{i, t} \cdot{ }^{2}$ In the absence of other constraints, the equilibrium level of the FDI stock would otherwise be either zero or infinity. The term $\ln F D I_{i, t}^{*}-\ln F D I_{i, t-1}$ implies that the self-reinforcing effect of $F D I_{i, t}$ diminishes as the actual stock approaches the equilibrium stock. The specification captures a process of gradual adjustment towards the equilibrium stock and is in line with the investment literature, which argues that the desired capital stock is attained gradually rather than instantaneously (Cheng and Kwan, 2000).

For empirical purpose we switch to the discrete version of (3) and approximate the derivative of $\ln \left(F D I_{i, t}\right)$ by $\ln \left(F D I_{i, t}\right)-\ln \left(F D I_{i, t-1}\right)$. With $f d i_{i, t}=\ln \left(F D I_{i, t}\right)$ we have

$$
\begin{aligned}
f d i_{i, t}-f d i_{i, t-1} & =\alpha\left(f d i_{i, t}^{*}-f d i_{i, t-1}\right) \\
& \Leftrightarrow f d i_{i, t}=(1-\alpha) f d i_{i, t-1}+\alpha f d i_{i, t}^{*}
\end{aligned}
$$

Note that for the process to be stable $(1-\alpha)$ needs to be a positive fraction. Expression (6) shows the observed FDI stock at time $t$ to be a result of a positive feedback effect, that propels the stock towards its equilibrium level, and of the changing equilibrium level itself.

In order to estimate (6) we need to specify the determinants of $F D I^{*}$. According to the type of foreign investment different factors might be decisive for the choice of location. Resource seeking investors will be attracted to locations with ceteris paribus low labour costs and good access to transport possibilities to the relevant markets. For market seeking investors local demand factors will be more important. Other factors might matter to both types of investors. Generally, any factor that affects the relative profitability of an investment location will also determine $F D I^{*}$. The importance of the following variables has been highlighted by earlier work ${ }^{3}$ : the market size of the host country, the country's openness to trade, wage costs adjusted for the quality of labour, and the riskiness of a location (specially for emerging markets). Chakrabarti (2001) performed an extreme bound analysis for a large cross-section of countries and found strong support for the explanatory power of host country

\footnotetext{
${ }^{2}$ In order to have agglomeration effects the opposite should hold.

${ }^{3}$ See e.g. Bevan and Estrin (2000), Bevan et al. (2004), Carstensen and Toubal (2004), Chakrabarti (2001) and references therein, Cheng and Kwan (2000), Garibaldi et al. (2001), Holland and Pain (1998), Kinoshita and Campos (2003), and Resmini (2000).
} 
market size. He further finds that a country's openness to trade, followed by wage costs, is more likely to be correlated with FDI than other determinants.

The specific nature of the transition process brings along some less standard determinants. First of all the key institutions underlying a market economy had to be put in place. Since the nature and the speed of institutional change differed widely across CEECs, institutional development may constitute a decisive factor in the choice of location by foreign investors. Especially the privatization of state-owned enterprises stands out as an institutional innovation that likely has borne a considerable impact on $F D I^{*}$. Privatization methods embodied substantial differences in the openness of the process to foreigners. Three broad categories of privatization methods can be distinguished, namely insider, voucher and direct sales privatization. Insider privatization is not conducive to foreign investors as the local firm is 'sold' to a combination of management and employees. These insiders have been very reluctant and slow to transfer their controlling powers to outside owners (see for example Filatotchev et al., 1999, for Russia). Voucher privatization allows citizens to trade vouchers (which they received for free) for shares in companies at primary privatization auctions. Citizens can do so directly or via intermediaries (for example the investment funds in the Czech Republic). In a later phase foreign investors can buy shares from the new private owners on the secondary market. Direct privatization sales where state firms are sold for cash to the highest bidder have in general been most open to foreign participation. In many cases foreigners had equal access to the auctions, or even were explicitly targeted as potential bidders as was the case in Hungary (see State Audit Office, Hungary, 2001 for an overview of the role of foreigners in Hungary's privatization process).

Finally, during the 1990s, the member states of the European Community and later the EU involved the CEECs in an accession process. Since EU membership implies certain standards in terms of macroeconomic and political stability and of the institutional and legal environment, the key announcements in the accession process may have affected foreign investment. For example, lower trade barriers between accession countries and the EU might be relevant for resource seeking investment.

\section{Data and estimation procedure}

The dataset contains bilateral FDI stocks in billions of 1996 EUR. The host countries are the eight new member states of the $\mathrm{EU}^{4}$, Bulgaria and Romania. The source countries are twelve

\footnotetext{
${ }^{4}$ Czech Republic, Estonia, Hungary, Latvia, Lithuania, Poland, Slovak Republic, and Slovenia.
} 
of the current EU member states. ${ }^{5}$ The data are drawn from the European Union Foreign Direct Investment Yearbook 2001 supplemented with data from the OECD International Direct Investment Statistics Yearbook. As we do not have data for all possible country pairs, we end up with 99 combinations. The data period covered is 1992-2000 for most of the cross-sections. Depending on the explanatory variables used the total number of observations is about 600 .

As measure for market potential we use real GDP in EUR, calculated as GDP in USD multiplied by the euro-dollar exchange rate, deflated by euro prices. These series are drawn from the IMF International Financial Statistics database (IFS). The cost of labour in the host countries is measured by average monthly wages in manufacturing, converted to euro. Average monthly wages are obtained from the ILO Handbook of Labour Statistics, exchange rates are taken from IFS. Foreign firms may be interested in wage levels because they bring their own productivity enhancing technology with them. However, the quality of labour will determine how well workers will be able to cope with the new technology. We consider unit labour costs rather than wages, because the former correct for labour productivity. Unit labour costs are calculated as average monthly wages divided by productivity, in turn calculated as GDP over employment. The latter again is taken from IFS. We expect a negative impact of unit labour costs. Given that we consider bilateral flows, we further transform the variable by making the ratio of host to source country unit labour costs. The closer to one, the smaller the difference between host and source country unit labour costs. Given our definition of host and source countries, the ratio will be smaller than one. We therefore expect a negative sign. ${ }^{6}$

Gravity models of international trade suggest that the distance between two countries can serve as a proxy for transportation (and informational) costs. The smaller the distance, the larger the expected trade volume between two countries. With respect to FDI, distance between host and source country may reflect opposing effects. The greater the distance, the more incentives to relocate production facilities to the host country and substitute FDI for exports. Distance will have the opposite effect however in case of resource seeking FDI intent on re-export to the source country Therefore we abandon distance and introduce integration between host and source country as explanatory variable. The variable is constructed as bilateral trade as a percentage of host country GDP. Bilateral exports and imports are taken from the IMF Direction of Trade Statistics. The variable measures the importance of the source country as trading partner for the host country and reflects the degree of integration.

\footnotetext{
${ }^{5}$ Austria, Belgium, Denmark, Finland France, Germany, Italy, the Netherlands, Portugal, Spain, Sweden, and the United Kingdom.

${ }^{6}$ Should the ratio be larger than one, the opposite would hold.
} 
At the same time it controls for the size of the source country, since gravity implies more bilateral trade with a larger source country. A significant positive coefficient indicates that for country pairs that are more integrated, the FDI stock of the source in the host is likely to be larger.

Investment decisions in emerging markets are also influenced by country risk. Risk ratings are provided on demand by specialized firms. These ratings are quite comprehensive and cover a broad range of underlying economic and political performance indicators. To the extent that we control for these factors in the regression, risk perception should no longer matter. Nevertheless it is interesting to see whether these ratings add to the explanatory power of our regressions. We use Euromoney country risk ratings. Because a higher value indicates less risk, a positive relation with FDI inflows can be expected. In the specific case of transition countries the perceived country risk is highly correlated with progress in reform. Resmini (2000) concludes that the path and the pace of structural reforms have been crucial for attracting FDI (her sample covers 1990-95). According to Kinoshita and Campos (2003) trade liberalization and a reduction in capital controls are most relevant to foreign investment among all the available indices of structural reform. If trade is positively associated with FDI, a more liberal trade regime will induce FDI. On the other hand, if FDI is motivated by avoiding trade restrictions, reduction of these restrictions will not induce more FDI. Restrictions to currency convertibility hamper import of inputs and repatriation of profits, phenomena that typically come along with FDI. In the empirical analysis we test for an effect of the progress in different areas of reform. In order to do so, the liberalization indicators taken from the yearly Transition Report, issued by the European Bank for Reconstruction and Development (EBRD), are added to the regressors. With respect to progress in the privatization process we use more detailed measures than the liberalization indicator from the Transition Report. We use separate indices for insider, voucher and direct privatization. The variables take the value 1 if the method concerned was the primary privatization method in a given year, 0.5 if it was the secondary, and 0.25 if was the tertiary method. ${ }^{7}$ The indicator takes into account whether privatization actually occurred or not. The data are taken from Garibaldi et al. (2001), and are updated with information from several recent issues of the Transition Report.

\footnotetext{
${ }^{7}$ For example in given year in specific country direct sales were commonly used for privatization, but also some voucher schemes were applied. Direct would then be 1, Voucher 0.5, and Insider 0. Should only direct sales have been used, Direct would be 1, Voucher 0, and Insider 0. If no privatization took place, all three variables equal zero. For a given year and a given country, it is not possible that 2 variables obtain the same score, except zero.
} 
The time-varying equilibrium level of FDI, $f d i_{i, t}^{*}$ can then be written as

$$
f d i_{i, t}^{*}=\beta^{\prime} X_{i, t}
$$

where $X_{i, t}$ is a vector of the determinants of $f d i_{i, t}^{*}$ discussed above. Substituting in (6) gives

$$
\begin{aligned}
f d i_{i, t} & =(1-\alpha) f d i_{i, t-1}+\alpha \beta^{\prime} X_{i, t} \\
& \Leftrightarrow f d i_{i, t}=\alpha\left(\beta^{\prime} X_{i, t}-f d i_{i, t-1}\right)+f d i_{i, t-1}
\end{aligned}
$$

For estimation we consider the following reparametrisation of (8). This is a dynamic panel regression with a lagged dependent variable on the right-hand side.

$$
\begin{aligned}
f d i_{i, t} & =\delta f d i_{i, t-1}+\gamma^{\prime} X_{i, t}+u_{i t} \\
u_{i t} & =\eta_{i}+\nu_{i t}
\end{aligned}
$$

The OLS estimator of (9) is inconsistent because the lagged dependent variable is positively correlated with the error term $\left(\eta_{i}+\nu_{i t}\right)$ due to the presence of the individual effects. Though the within estimator eliminates this source of inconsistency by transforming the equation to eliminate $\eta_{i}$, it introduces a non-negligible correlation between the transformed lagged dependent variable and the transformed error term. This then gives rise to a new source of inconsistency (see Nickell, 1981). Arellano and Bond (1991) propose to apply a GMM-estimator on the first-differenced version of (9).

$$
\Delta f d i_{i, t}=\delta \Delta f d i_{i, t-1}+\gamma^{\prime} \Delta X_{i, t}+\Delta u_{i, t}
$$

where the cross-section specific effects are eliminated by first-differencing. The transformed specification suggests an instrumental variables approach. $f d i_{i, t-2}$ is correlated with $f d i_{i, t-1}-f d i_{i, t-2}$, but not with $\Delta u_{i, t}=\nu_{i, t}-\nu_{i, t-1}$ under the assumption of no autocorrelation in the level residuals. ${ }^{8}$ Provided $T \geq 3$, the two period lagged level of the dependent variable can be used to identify $\alpha$. Arellano and Bond (1991) suggest the following extended list of instruments for the first-differenced equations. More precisely, rather than using only $f d i_{i, T-2}$ as instrument for the first-differenced equation in period $T, f d i_{i 1}, f d i_{i 2}, \ldots, f d i_{i, T-2}$

\footnotetext{
${ }^{8}$ The only further assumption required is that the initial conditions $f d i_{i 1}$ are uncorrelated with the subsequent disturbances, i.e.

$$
E\left(f d i_{i 1} \nu_{i t}\right)=0 \text { for } i=1, \ldots, N \text { and } t=2, \ldots, T
$$
}


are available as instruments.

$$
E\left(f d i_{i, t-s} \Delta \nu_{i t}\right)=0 \quad t=3, \ldots, T \text { and } s \geq 2
$$

In the case of multivariate analysis the explanatory variables can be used as additional instruments. For strictly exogenous variables $x$, both past and future values are valid instruments. In the case of reverse causality, $x$ is said to be only weakly exogenous or predetermined. Then only suitably lagged values of $x$ qualify as valid instruments. This gives rise to the following moment conditions. For the strictly exogenous variables, $e_{i, t-s}$, in $X_{i, t}$

$$
E\left(e_{i, t-s} \Delta \nu_{i t}\right)=0 \quad t=3, \ldots, T \text { and all } s
$$

and for predetermined variables, $p_{i, t-s}$, in $X_{i, t}$

$$
E\left(p_{i, t-s} \Delta \nu_{i t}\right)=0 \quad t=3, \ldots, T \text { and } s \geq 2
$$

The first-differenced GMM estimator has been found to have poor finite sample properties (bias and imprecision) when the lagged levels of the series are only weakly correlated with subsequent first differences, so that the instruments available for the first-differenced equations are weak (Blundell and Bond, 1999). This is the case in our dataset as the correlation between $\Delta f d i_{i, t}$ and $f d i_{i, t-1}$ is only $-0.36 .{ }^{9}$ Blundell and Bond (1998) suggest to augment the first-differenced moment conditions by the following level moment conditions to improve the efficiency of the GMM-estimator.

$$
E\left(\left(\eta_{i}+\nu_{i t}\right) \Delta f d i_{i, t-1}\right)=0 \quad \text { for } t=3, \ldots, T
$$

Level moment conditions for the explanatory variables can be added accordingly:

$$
E\left(\left(\eta_{i}+\nu_{i t}\right) \Delta e_{i, t-s}\right)=0 \quad t=2, \ldots, T \text { and all } s
$$

for strictly exogenous $e_{i, t-s}$ in $X_{i, t}$, and for predetermined $p_{i, t-s}$ in $X_{i, t}$

$$
E\left(\left(\eta_{i}+\nu_{i t}\right) \Delta p_{i, t-s}\right)=0 \quad t=3, \ldots, T \text { and } s \geq 1
$$

The GMM estimation based on the moment conditions (11)-(16) can be performed in one step or in two steps. The difference between both estimators is that the one-step estimator

\footnotetext{
${ }^{9}$ The correlation for the main explanatory variables is: -0.07 for GDP of the host country, -0.28 for relative unit labour costs, and 0.21 for the integration variable.
} 
is asymptotically efficient only under homoskedasticity of the $\nu_{i t}$, while two-step estimator does not require homoskedasticity to be asymptotically efficient. Nevertheless, a lot of applied work has focused on the one-step GMM estimator rather than the two-step version because the two-step weight matrix depends on estimated parameters. This makes the usual asymptotic distribution approximations less reliable for the two-step estimator. Simulation studies have shown that the asymptotic standard errors tend to be much too small. Equivalently the asymptotic t-ratios are much too big when using the two-step estimator, whereas the equivalent tests based on the one-step estimator are quite accurate. Windmeijer (2000) provides a formal analysis of the issue, and proposes a finite sample correction for the asymptotic variance of the two-step GMM estimator. We use the two-step estimator and present corrected standard errors. ${ }^{10}$

We check the overall validity of the moment conditions by the Hansen test of overidentifying restrictions. The null hypothesis of no misspecification is rejected if the minimized GMM criterion function registers a large value compared with a $\chi^{2}$-distribution with the degree of freedom equal to the difference between the number of moment conditions and number of parameters. We also test the key identifying assumption that there is no serial correlation in the $\nu_{i t}$ disturbances: if the level residuals are indeed serially uncorrelated, then, by construction, the first-differenced residuals in (10) would follow an MA(1) process which implies first-order autocorrelation, but no higher order autocorrelation. Based on the first-differenced residuals, the Arellano-Bond $m 1$ and $m 2$ statistics test the null hypotheses of zero first- and second-order autocorrelation, respectively (see Arellano and Bond (1991) for further details). An insignificant $m 1$ or significant $m 2$ will issue warnings against the likely presence of invalid moment conditions due to serial correlation in the level residuals.

\section{Results}

Tables 3,4 , and 5 contain the empirical results. The tests for first and second order autocorrelation and the Hansen test for overidentifying restrictions are satisfactory in all cases. We do not report $p$-values for the $m 1$-test because they are all smaller than 0.01 . The displayed coefficients in the tables are based on the reparametrisation in (9) and thus show $\delta$ and $\gamma^{\prime}$. To interpret the estimated coefficients in the original model we need to perform some recalculations. To derive the speed of adjustment, $\alpha$, we subtract the estimated coefficient of lagged FDI from 1 (i.e. $\alpha=1-\delta$ ). In order to retrieve the impact of the determinants on the equilibrium level of FDI, i.e. $\beta^{\prime}$ s in (7), the estimated coefficients $\gamma^{\prime}(c f .(9))$ are divided

\footnotetext{
${ }^{10}$ In a comparable analysis Carstensen and Toubal (2004) present highly significant coefficients. As they do not deal with the issue of the standard errors, some caution may be warranted.
} 


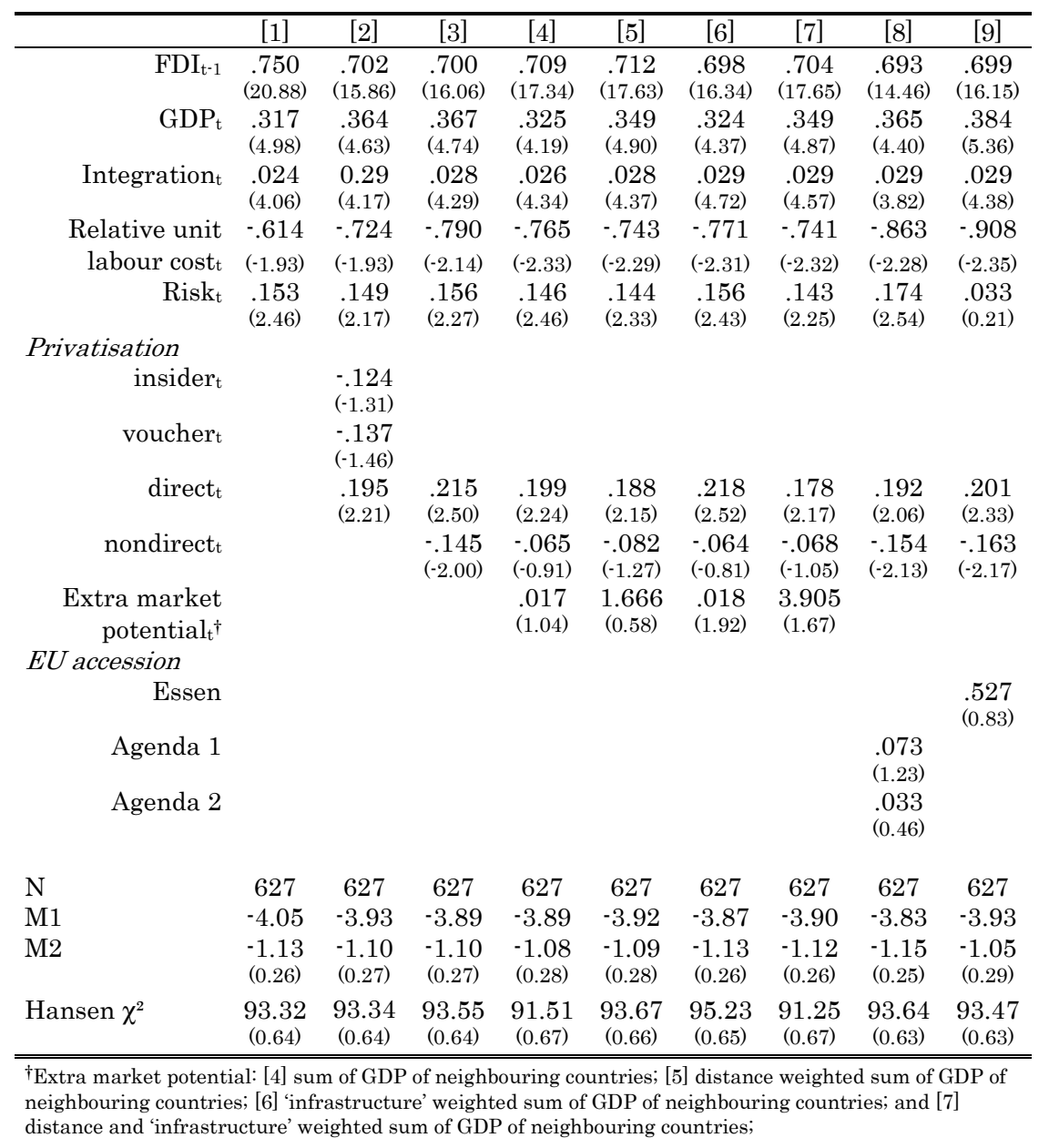

Table 3: Basic results

by 1 minus the coefficient of lagged FDI (i.e. $\beta^{\prime}=\frac{\gamma^{\prime}}{1-\delta}$ ). Below, we interpret results in terms of the original framework and the impact of the variables is calculated accordingly. Table 3 contains the basic results. In table 4 we present a more detailed analysis of the impact of privatization strategies on FDI. Table 5 is concerned with the effect of different institutions.

\subsection{Basic results}

Specification [1] in table 3 presents results for the traditional determinants. In addition to the lagged FDI stock, following from the partial adjustment specification, we use four variables as determinants of the equilibrium stock: GDP, relative unit labour costs, the risk indicator, and the integration variable. From specification [1] in table 3 we see that the lagged FDI stock is statistically significant in explaining the current FDI stock. The point estimate of 0.75 (i.e. $\delta)$ implies an adjustment speed of $0.25(\alpha=1-\delta)$. Specifications [2] to [9] result in an adjustment speed of about 0.3. The latter value implies an adjustment path 


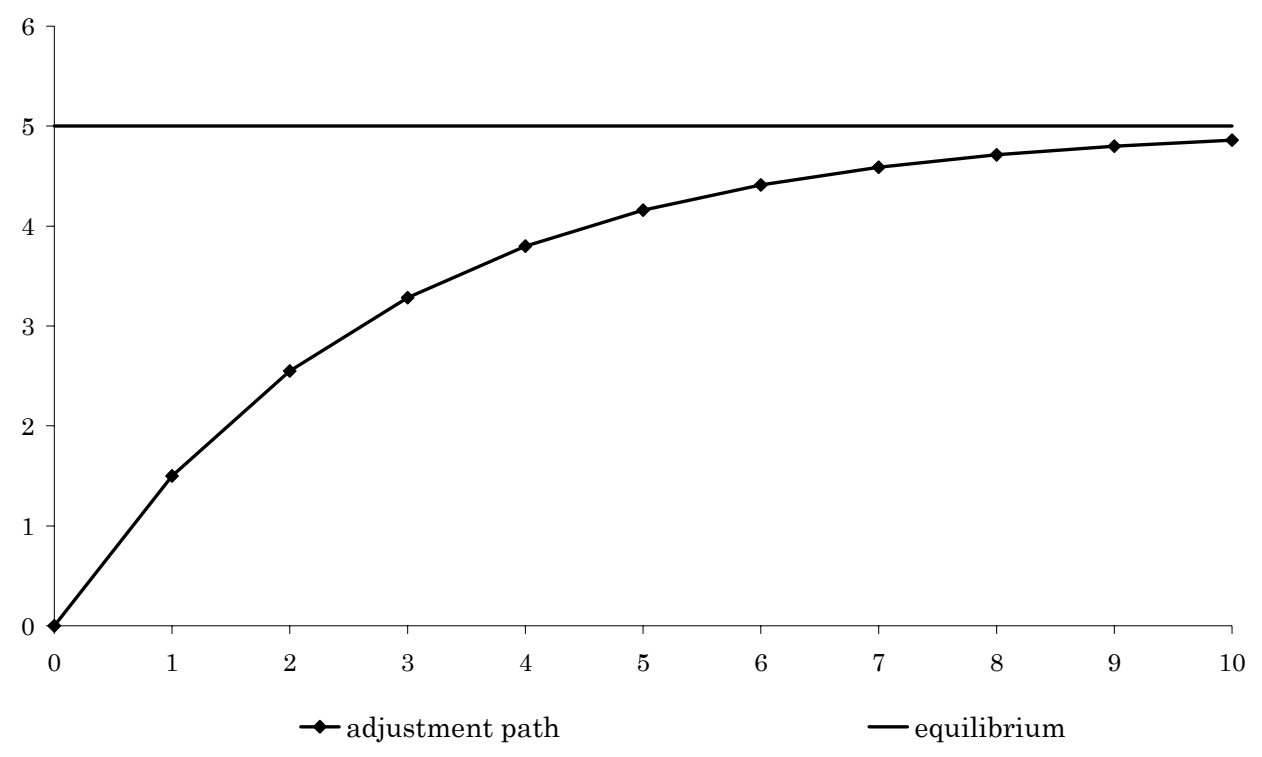

Figure 1: Adjustment path towards the time-invariant equilibrium

as shown in figure 1 where the equilibrium value is assumed to be $5.02^{11}$ and the starting value is set at zero. The adjustment is quite rapid and after five periods about $80 \%$ of the initial gap is closed already. ${ }^{12}$

The significant positive impact of GDP suggests that the market access mechanism is present. A $1 \%$ increase in GDP results in an increase of $0.32 /(1-0.75)=1.27 \%$ of the equilibrium FDI stock, $F D I^{*}$. The integration variable is statistically significant and is positively signed. An increase in bilateral trade integration of 10\%-point is associated with an increase of about $0.96 \%$ of $F D I^{*}$. Relative unit labour costs have the expected impact. As the gap between host and source country unit labour costs becomes smaller, i.e. an increase in the relative unit labour costs, $F D I^{*}$ is negatively affected. If for example the relative unit labour costs increase from 0.4 to $0.5, F D I^{*}$ decreases with $0.24 \%$. The risk variable is significant and has the expected sign. An increase in the risk variable with $1 \%$, i.e. a reduction of the risk, increases $F D I^{*}$ with about $0.612 \%$.

In [2] we add the privatization strategy used by the host country to the explanatory variables. We consider three categories of privatization: direct, voucher and insider privati-

\footnotetext{
${ }^{11}$ This is the average value of the natural logarithm of the stock of FDI for the period 1995-2000 for the average bilateral country pair. This makes EUR 148.4bn. We use a time-invariant equilibrium to disentangle the adjustment to the equilibrium from changes in the equilibrium.

${ }^{12} \mathrm{~A}$ solution to $f d i_{t+1}-(1-\alpha) f d i_{t}=\alpha f d i^{*}$ is $f d i_{t}=A(1-\alpha) t+f d i^{*}$. For the initial level at $t=0$ we have $f d i_{0}=A+f d i^{*}$. The initial gap thus equals $A$. The gap will be halved when $f d i_{t}-f d i^{*}=\frac{1}{2} A$. With $\alpha=0.3$ this is the case after 1.94 period.
} 
zation. Direct privatization has a significant positive impact on $F D I^{*}$, whereas insider and voucher privatization are negative but not significant. Since we cannot reject their point estimates to be equal we combine voucher and insider privatization in the category non-direct privatization. Specification [3] suggests that a non-direct method as primary strategy lowers $F D I^{*}$ with 1.79 billion EUR on average. ${ }^{13}$

Specifications [4] to [7] test additional dimensions of a country's market potential. In [4] and [5] we add the sum of the GDPs of the neighbouring transition countries to the other left hand side variables, the difference between [4] and [5] is that in [5] the respective GDPs are weighted by the inverse of the distance between the host country capital and the neighbour countries' capitals. While the conclusions with respect to the core variables arising from [3] remain unaffected, the extra market potential does not seem to enhance a country's attractiveness. In [6] and [7] we use infrastructure as an additional weight to determine the potential arising from neighbouring countries. Infrastructure is defined as the ratio of kilometres of paved roads over country surface. The underlying assumption is that countries that are connected through a better road network are more easily accessible and therefore constitute a bigger market potential. In [6] the infrastructure weighted GDP of neighbouring countries is significant at the 5\%-level. In [7] the distance and infrastructure weighted additional market potential is significant at the $10 \%$-level. The main conclusions with respect to the other variables are unaffected. ${ }^{14}$

Finally, in [8] and [9] we introduce EU integration announcement variables. The variables AG1 and AG2 in [8] reflect the division between first and second wave accession countries, identified in the Agenda 2000 document of the European Commission. The decision was taken at the Amsterdam 1997 IGC. AG1 is a dummy variable that takes the value 1 in the period 1997-99 for the first wave countries, AG2 is defined along the same lines but for second wave countries. ${ }^{15}$ Both variables are not statistically different from zero. Noteworthy is that AG1 is much larger and closer to significance than AG2. The ESSEN-variable in [9] reflects the launch of the pre-accession strategy at the Essen European Council in December 1994. The variable takes the value of 1 from 1995 onwards. As can be seen from table 3, we neither find a significant impact for this variable. This is in line with Bevan and Estrin (2000) who find no announcement effects for the level of FDI. Only after switching to changes in inflows

\footnotetext{
${ }^{13} F D I^{*}$ of 1.79 corresponds to $f d i^{*}$ of 0.58 .

${ }^{14}$ We also tested the EBRD index of trade and foreign exchange, import duties, and taxes on international trade as other possible weights along the lines of infrastructure. These were never significant but again left the core (qualitatively) unaffected.

${ }^{15}$ The first wave countries are the Czech Republic, Estonia, Hungary, Poland, and Slovenia; the second wave roup consists of Bulgaria, Latvia, Lithuania, Romania, and the Slovak Republic. In 2000 eight of the ten applicants were announced to be entering the EU in 2004. The difference between first and second wave then disappears. Bulgaria and Romania will enter the EU in a later stage.
} 


\begin{tabular}{|c|c|c|c|c|c|}
\hline & [1] & [2] & {$[3]^{\dagger \dagger}$} & {$[4] \dagger$} & [5] \\
\hline $\mathrm{FDI}_{\mathrm{t}-1}$ & $\begin{array}{l}.628 \\
(11.57)\end{array}$ & $\begin{array}{l}.626 \\
(11.86)\end{array}$ & $\begin{array}{l}.654 \\
(13.24)\end{array}$ & $\begin{array}{l}.694 \\
(10.75)\end{array}$ & $\begin{array}{c}.642 \\
(11.81)\end{array}$ \\
\hline $\mathrm{FDI}_{\mathrm{t}-1}{ }^{*}$ direct & & & $\begin{array}{l}-.007 \\
(-0.32)\end{array}$ & $\begin{array}{l}-.011 \\
(-0.64)\end{array}$ & \\
\hline FDI $_{t-1}{ }^{*}$ nondirect & & & $\begin{array}{l}-.038 \\
(-1.99)\end{array}$ & $\begin{array}{l}-.023 \\
(-2.07)\end{array}$ & $\begin{array}{l}-.041 \\
(-2.62)\end{array}$ \\
\hline $\mathrm{GDP}_{\mathrm{t}}$ & $\begin{array}{l}.434 \\
(4.72)\end{array}$ & $\begin{array}{l}.432 \\
(4.78)\end{array}$ & $\begin{array}{l}.421 \\
(5.38)\end{array}$ & $\begin{array}{l}.407 \\
(4.87)\end{array}$ & $\begin{array}{l}.437 \\
(4.64)\end{array}$ \\
\hline Integration $_{t}$ & $\begin{array}{l}.038 \\
(4.44)\end{array}$ & $\begin{array}{l}.037 \\
(4.29)\end{array}$ & $\begin{array}{l}.040 \\
(4.20)\end{array}$ & $\begin{array}{l}.036 \\
(3.62)\end{array}$ & $\begin{array}{l}.039 \\
(3.91)\end{array}$ \\
\hline $\begin{array}{l}\text { Relative unit } \\
\text { labour cost }\end{array}$ & $\begin{array}{l}-1.189 \\
(-2.85)\end{array}$ & $\begin{array}{l}-1.260 \\
(-2.85)\end{array}$ & $\begin{array}{l}-1.316 \\
(-2.78)\end{array}$ & $\begin{array}{l}-1.076 \\
(-2.36)\end{array}$ & $\begin{array}{l}-1.180 \\
(-2.18)\end{array}$ \\
\hline Risk $_{\mathrm{t}}$ & $\begin{array}{l}.127 \\
(1.66)\end{array}$ & $\begin{array}{l}.150 \\
(1.94)\end{array}$ & $\begin{array}{l}.161 \\
(2.53)\end{array}$ & $\begin{array}{l}.110 \\
(1.71)\end{array}$ & $\begin{array}{l}.130 \\
(1.72)\end{array}$ \\
\hline \multicolumn{6}{|l|}{ Privatisation } \\
\hline direct $_{t}$ & $\begin{array}{l}.165 \\
(1.83)\end{array}$ & $\begin{array}{l}.199 \\
(2.13)\end{array}$ & $\begin{array}{l}.179 \\
(1.78)\end{array}$ & $\begin{array}{l}.218 \\
(2.00)\end{array}$ & $\begin{array}{l}.224 \\
(2.03)\end{array}$ \\
\hline nondirect $_{t}$ & $\begin{array}{l}-.007 \\
(-0.10)\end{array}$ & $\begin{array}{l}-.058 \\
(-0.74)\end{array}$ & $\begin{array}{l}-.007 \\
(-0.08)\end{array}$ & $\begin{array}{l}.016 \\
(0.20)\end{array}$ & $\begin{array}{l}-.027 \\
(-0.33)\end{array}$ \\
\hline $\begin{array}{r}\text { Cumulative } \\
\text { direct }_{t-1}\end{array}$ & $\begin{array}{l}.062 \\
(2.26)\end{array}$ & & & & \\
\hline $\begin{array}{l}\text { Cumulative } \\
\text { nondirect } t_{t-1}\end{array}$ & $\begin{array}{l}.057 \\
(2.35)\end{array}$ & & & & \\
\hline $\begin{array}{l}\text { Cumulative } \\
\text { direct-nondir }{ }_{\mathrm{t}-1}\end{array}$ & & $\begin{array}{l}.055 \\
(2.66)\end{array}$ & $\begin{array}{l}.053 \\
(2.96)\end{array}$ & $\begin{array}{l}.052 \\
(2.60)\end{array}$ & $\begin{array}{l}.050 \\
(2.44)\end{array}$ \\
\hline $\mathrm{N}$ & 579 & 579 & 579 & 579 & 579 \\
\hline M1 & -3.70 & -3.70 & -3.73 & -3.76 & -3.64 \\
\hline M2 & $\begin{array}{l}-1.10 \\
(0.27)\end{array}$ & $\begin{array}{l}-1.11 \\
(0.27)\end{array}$ & $\begin{array}{l}-1.18 \\
(0.24)\end{array}$ & $\begin{array}{l}-1.04 \\
(0.30)\end{array}$ & $\begin{array}{l}-1.19 \\
(0.24)\end{array}$ \\
\hline Hansen $\chi^{2}$ & $\begin{array}{l}91.60 \\
(0.69)\end{array}$ & $\begin{array}{l}93.94 \\
(0.62)\end{array}$ & $\begin{array}{l}93.50 \\
(0.65)\end{array}$ & $\begin{array}{l}92.79 \\
(0.65)\end{array}$ & $\begin{array}{r}93.77 \\
(0.60)\end{array}$ \\
\hline
\end{tabular}

${ }_{\dagger}$ For the effect on the speed of adjustment [3] uses last year's privatization strategies, [4] the strategies of the last 2 years

Table 4: FDI and privatisation schemes

and considering only announcement effects for Visegrad countries they find some impact. Since the start of transition it has been expected that the CEECs would either join the EU or integrate their economies with the EU, regardless the official announcements by the EU. Our results therefore do not necessarily mean that EU enlargement bore no effect on FDI, but rather that the timing of the formal steps in the enlargement process did not cause major shifts in foreign investment. Furthermore we only employ data on accession countries, and the cross-section dimension of the panel may therefore be too limited to observe an effect.

\subsection{FDI and privatization}

In table 4 we investigate the relationship between privatization and FDI more thoroughly. Since most of the enterprises were state-owned at the outset of transition, their privatization potentially offered opportunities for brownfield FDI. A broad array of privatization techniques was used across countries. During transition, countries switched methods or used combinations of methods. As we confirmed in table 3 not all methods are equally well suited 


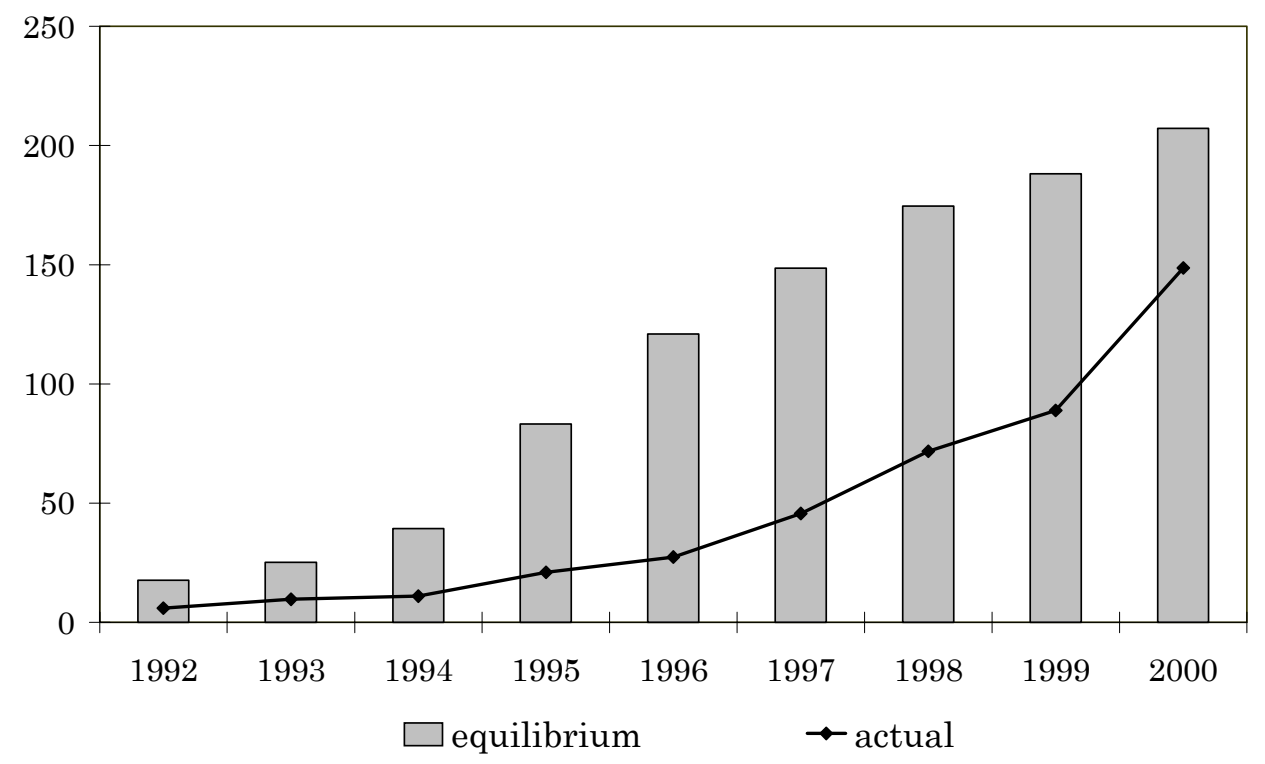

Figure 2: Actual average FDI stock and equilibrium FDI stock implied by [2] in table 4 (billions of EUR)

to attract foreign investment. Not only current privatization, but the entire privatization history is likely to bear an impact on $F D I_{t}^{*}$. We capture privatization history by the one period lagged cumulative direct and non-direct indices. From [1] in table 4 one can infer that both the direct and non-direct privatization history have a significant positive impact. Since we cannot reject their impact to be equal, we re-estimate with [2] as result. Privatization history, independent from the method used, has a positive impact on $F D I_{t}^{*}$. This probably reflects that privatization is only the first step in a series of changes in ownership, so that eventually the opportunities for foreigners to invest are no longer related to the privatization method used. This is in line with the findings of Frydman et al. (1999) that not the privatization method per se, but the resulting ownership type is decisive for firm performance. Figure 2 plots the actual FDI stock and the equilibrium implied by specification [2] for the average bilateral country pair.

The relationship between FDI and privatization may be even more complex. We did not find a concurrent impact of non-direct privatization. Nevertheless, voucher and insider privatization schemes may have served as a dissuasive signal, because they were partly induced by the fear of selling out to foreigners. This may lead foreign investors to postpone or even restrain them from their planned investment. Furthermore, non-direct methods often resulted in a sort of entrenchment as insiders clung to control over the firm and blocked restructuring. New investors will then also be less eager to invest in the country because the scope for 


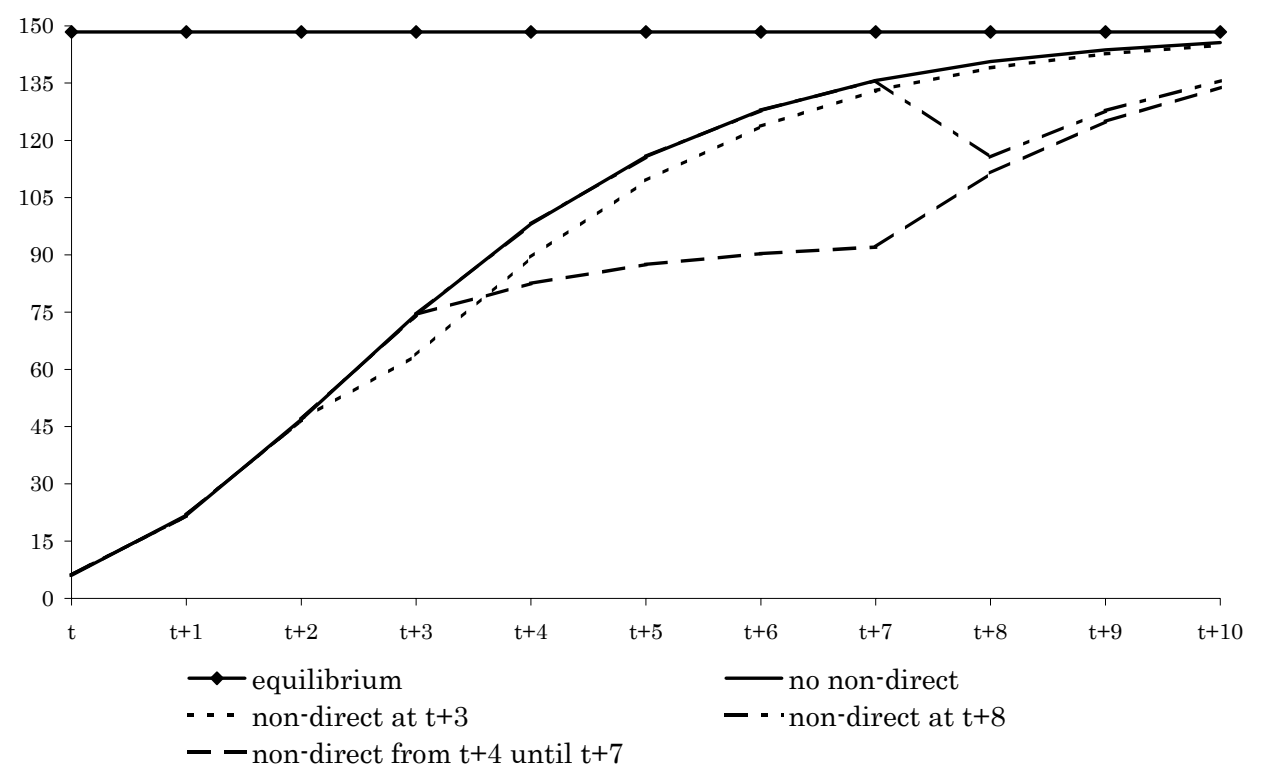

Figure 3: Impact of non-direct privatisation on the adjustment path to the time-invariant equilibrium

positive externalities from domestic firms is smaller. This suggests that rather than affecting the equilibrium itself, non-direct methods of privatization slow down the adjustment to the equilibrium. We test this by transforming (9), where vice versa we also allow that direct privatization schemes speed up adjustment to equilibrium:

$$
\begin{aligned}
f d i_{i, t}= & \delta\left(1+\kappa_{1} \text { nondirect }_{t-1}+\kappa_{2} \text { direct }_{t-1}\right) f d i_{i, t-1} \\
& +\gamma^{\prime} X_{i, t}+\varepsilon_{i t} \\
\Leftrightarrow & f d i_{i, t}=\delta f d i_{i, t-1}+\delta_{\kappa 1} \text { nondirect }_{t-1} f d i_{i, t-1} \\
& +\delta_{\kappa 2} \text { direct }_{t-1} f d i_{i, t-1}+\gamma^{\prime} X_{i, t}+\varepsilon_{i t}
\end{aligned}
$$

Columns [3] in table 4 confirms our hypothesis that the use of non-direct methods slows down adjustment. The point estimate is small but significant. The coefficient of lagged FDI varies between 0.6 and 0.7 and is reduced by about 0.04 . Direct privatization does not seem to affect the speed of adjustment. Results with respect to the other variables remain unaffected. In column [4] we consider privatization strategies of the last 2 years, rather than just last year. The dampening impact on the speed of adjustment is now significant at the $5 \%$-level. Since the no privatization observations are limited, the correlation between direct and non-direct is fairly high. Therefore [5] excludes the impact of direct privatization on the 
speed of adjustment. The significance level of the interaction term increases to the 1\%-level. Based on specification [3], figure 3 plots the impact of non-direct privatization in a given period on the adjustment path to a time-invariant equilibrium level of about EUR 148.4bn. ( $c f$. footnote 11). Since the impact (i.e. $\delta_{\kappa 1}$ nondirect $_{t-1} f d i_{i, t-1}$ ) is related to the lagged stock of FDI $\left(f d i_{i, t-1}\right)$, the impact of non-direct privatization on the adjustment speed is larger, the higher the lagged stock of FDI. Figure 3 also reveals that a prolonged period of non-direct privatization considerably slows down catch-up to the equilibrium.

Summarizing, our evidence suggests that current direct privatization has an immediate positive effect on the equilibrium level of FDI, while current non-direct privatization negatively slows down adjustment to equilibrium. Privatization history positively affects the equilibrium level of FDI independently of the method used.

\subsection{FDI and institutions}

Following the increasing literature that relates institutions to economic outcomes, institutions increasingly are stressed as potential locational advantages (see e.g. Kinoshita and Campos, 2003, Bevan et al., 2004). In the previous section we elaborated on the complex relationship between FDI and privatization. However, the entire institutional framework of the socialist economies had to be rebuilt from scratch. This process resulted in wide variety of approaches across countries. The EBRD provides indicators of progress in different areas of institutional reform in its yearly Transition Report. This allows us to test which institutions matter to foreign investors and which not. The risk indicator may have picked up the general institutional context in previous specifications. We therefore replace the risk indicator with various indicators of reform. Since foreign investors face costs for adaptation to an incomplete institutional environment, we expect a positive relation between reform and investment.

In addition to the average level of reform we test for the impact of reform in the following areas: prices, trade and foreign exchange, competition policy, banking reform, and reform of non-banking financial institutions. Table 5 presents results for these different institutions. The average reform indicator used in column [1] is a simple average of the EBRD indicators, excluding the indicators for small and large scale privatization since we already extensively control for privatization efforts. We find a significant positive coefficient. An increase of $1 \%$ in the level of average reform is associated with an increase of $1.34 \%$ in $F D I^{*}$. This points to the crucial role of the stage of development of institutions in attracting FDI, for in quantitative terms the point estimate of the coefficient implies a large positive contribution to FDI. 


\begin{tabular}{|c|c|c|c|c|c|c|}
\hline & [1] & {$[2]$} & {$[3]$} & {$[4]$} & {$[5]$} & {$[6]$} \\
\hline $\mathrm{FDI}_{\mathrm{t}-1}$ & $\begin{array}{c}.622 \\
(12.13)\end{array}$ & $\begin{array}{c}.680 \\
(13.58)\end{array}$ & $\begin{array}{c}.661 \\
(12.22)\end{array}$ & $\begin{array}{c}.670 \\
(12.10)\end{array}$ & $\begin{array}{c}.673 \\
(14.33)\end{array}$ & $\begin{array}{c}.691 \\
(13.02)\end{array}$ \\
\hline $\mathrm{FDI}_{\mathrm{t}-1} *$ direct & $\begin{array}{l}-.011 \\
(-0.48)\end{array}$ & $\begin{array}{l}-.019 \\
(-0.84)\end{array}$ & $\begin{array}{l}-.002 \\
(-0.08)\end{array}$ & $\begin{array}{l}-.010 \\
(-0.46)\end{array}$ & $\begin{array}{l}-.016 \\
(-0.71)\end{array}$ & $\begin{array}{l}-.012 \\
(-0.48)\end{array}$ \\
\hline $\mathrm{FDI}_{\mathrm{t}-1} *$ nondirect & $\begin{array}{l}-.039 \\
(-2.26)\end{array}$ & $\begin{array}{l}-.042 \\
(-2.58)\end{array}$ & $\begin{array}{l}-.037 \\
(-1.94)\end{array}$ & $\begin{array}{l}-.042 \\
(-2.29)\end{array}$ & $\begin{array}{l}-.041 \\
(-2.20)\end{array}$ & $\begin{array}{l}-.043 \\
(-2.28)\end{array}$ \\
\hline $\mathrm{GDP}_{\mathrm{t}}$ & $\begin{array}{r}.423 \\
(5.13)\end{array}$ & $\begin{array}{l}.389 \\
(5.14)\end{array}$ & $\begin{array}{l}.422 \\
(5.24)\end{array}$ & $\begin{array}{l}.410 \\
(4.65)\end{array}$ & $\begin{array}{l}.429 \\
(5.75)\end{array}$ & $\begin{array}{l}.451 \\
(6.66)\end{array}$ \\
\hline Integration $_{\mathrm{t}}$ & $\begin{array}{l}.039 \\
(3.82)\end{array}$ & $\begin{array}{l}.037 \\
(3.72)\end{array}$ & $\begin{array}{l}.039 \\
(4.01)\end{array}$ & $\begin{array}{l}.039 \\
(3.62)\end{array}$ & $\begin{array}{l}.039 \\
(4.39)\end{array}$ & $\begin{array}{l}.038 \\
(3.68)\end{array}$ \\
\hline $\begin{array}{l}\text { Relative unit } \\
\text { Labour costst }\end{array}$ & $\begin{array}{l}-1.119 \\
(-2.37)\end{array}$ & $\begin{array}{l}-1.663 \\
(-4.07)\end{array}$ & $\begin{array}{l}-1.140 \\
(-2.71)\end{array}$ & $\begin{array}{l}-.720 \\
(-1.92)\end{array}$ & $\begin{array}{l}-.970 \\
(-2.30)\end{array}$ & $\begin{array}{l}-.567 \\
(-1.75)\end{array}$ \\
\hline $\begin{array}{l}\text { Privatisation } \\
\text { direct } t_{t}\end{array}$ & $\begin{array}{l}.183 \\
(1.90)\end{array}$ & $\begin{array}{l}.127 \\
(1.26)\end{array}$ & $\begin{array}{l}.202 \\
(1.94)\end{array}$ & $\begin{array}{l}.242 \\
(2.35)\end{array}$ & $\begin{array}{l}.171 \\
(1.60)\end{array}$ & $\begin{array}{l}.302 \\
(2.58)\end{array}$ \\
\hline nondirect $_{\mathrm{t}}$ & $\begin{array}{l}-.009 \\
(-0.11)\end{array}$ & $\begin{array}{l}-.025 \\
(-0.33)\end{array}$ & $\begin{array}{l}.004 \\
(0.05)\end{array}$ & $\begin{array}{l}.027 \\
(0.35)\end{array}$ & $\begin{array}{l}-.019 \\
(-0.24)\end{array}$ & $\begin{array}{l}.080 \\
(0.93)\end{array}$ \\
\hline cdirnondir ${ }_{\mathrm{t}-1}$ & $\begin{array}{l}.040 \\
(2.18)\end{array}$ & $\begin{array}{l}.044 \\
(2.36)\end{array}$ & $\begin{array}{l}.047 \\
(2.60)\end{array}$ & $\begin{array}{l}.039 \\
(1.88)\end{array}$ & $\begin{array}{l}.036 \\
(2.05)\end{array}$ & $\begin{array}{c}.051 \\
(2.18)\end{array}$ \\
\hline Institution ${ }^{\dagger}$ & $\begin{array}{l}.506 \\
(2.05)\end{array}$ & $\begin{array}{l}.912 \\
(3.71)\end{array}$ & $\begin{array}{c}.352 \\
(2.32)\end{array}$ & $\begin{array}{c}.301 \\
(1.78)\end{array}$ & $\begin{array}{c}.416 \\
(1.82)\end{array}$ & $\begin{array}{l}-.177 \\
(-0.80)\end{array}$ \\
\hline $\mathrm{N}$ & 579 & 579 & 579 & 579 & 579 & 579 \\
\hline M1 & -3.73 & -3.85 & -3.78 & -3.72 & -3.81 & -3.79 \\
\hline M2 & $\begin{array}{l}-1.07 \\
(0.28)\end{array}$ & $\begin{array}{l}-1.02 \\
(0.31)\end{array}$ & $\begin{array}{l}-1.03 \\
(0.30)\end{array}$ & $\begin{array}{l}-0.98 \\
(0.33)\end{array}$ & $\begin{array}{c}-1.18 \\
(0.236)\end{array}$ & $\begin{array}{l}-1.09 \\
(0.28)\end{array}$ \\
\hline Hansen $\chi^{2}$ & $\begin{array}{c}91.44 \\
(0.66)\end{array}$ & $\begin{array}{c}89.12 \\
(0.67)\end{array}$ & $\begin{array}{c}93.38 \\
(0.64)\end{array}$ & $\begin{array}{c}92.57 \\
(0.65)\end{array}$ & $\begin{array}{c}91.03 \\
(0.66)\end{array}$ & $\begin{array}{c}90.05 \\
(0.67)\end{array}$ \\
\hline
\end{tabular}

Table 5: FDI and institutional development

The creation of markets has been one of the core elements of the transition to a market economy. In this respect, the liberalization of prices in both domestic and international markets was one of the crucial reform steps. As foreign investors usually prefer to operate on competitive domestic markets, price liberalization creates new business opportunities for them. The abolition of exchange restrictions and multiple exchange rates allows to repatriate profits and reduces transaction costs. ${ }^{16}$ For both price reform and trade \& foreign exchange reform, we find strongly significant positive coefficients (see columns [2] and [3]). This reflects that it is more interesting to invest in markets that have been liberalized and where there is free competition. Competition policy is important to protect consumers but can also be (ab)used to inhibit foreign entry. This is of particular concern for investors in industries with incumbent national monopolists (for example telecommunications). As old monopolies are broken, new possibilities are offered to foreign investors. Initially neglected, the design and implementation of competition policy has proven to be a complex process, that lagged the liberalization of markets for goods and services. In addition to the mere existence of rules,

\footnotetext{
${ }^{16}$ Established foreign-owned firms that benefit from barriers to entry, however, will oppose this type of reform.
} 
enforcement is necessary as well. Weak enforcement of regulatory policies tends to favour incumbent firms or firms with access to political and bureaucratic decision makers. Changes in competition policy therefore may change the relative competitiveness of firms operating in a given market and provide opportunities for entry of foreign firms with a competitive advantage. The results in [4] show a positive effect of improvements in competition policy. It is significant at the $10 \%$-level.

Progress in establishing financial infrastructure and capital markets facilitates access to complementary local financing for foreign investors and reduces transaction costs for local financial services. Further, better access to local finance helps to reduce the exposure to the exchange rate risk. A better financial architecture reduces payment system risk and increases the stability of the banking system. Local customers are also more likely to gain access to bank credit. This may accelerate demand for goods that are often bought on credit, e.g. up-market consumer durables. Financial reform should thus increase business opportunities for foreign investors. We find that banking reform in [5] is significant at the $10 \%$-level. A smoother working financial sector thus seems to increase the attractiveness of a location. Reform of non-banking financial institutions, on the other hand, is of no importance to foreign direct investors as appears from [6].

\section{Conclusions}

Given the state of institutional and economic development, there is an equilibrium level of foreign involvement in an economy. The collapse of the central planning system initiated a flow of foreign investment to the CEECs. We think of FDI flows as a process of partial adjustment towards the equilibrium level of the FDI stock. The observed FDI stock then reflects the impact of two driving forces. First, there is a 'positive feedback' effect that drives the stock towards its equilibrium level, even without changes in other determinants. Second, during the course of transition the determinants of the equilibrium level of FDI have changed. As a result the equilibrium level itself has shifted over time.

We employ a dataset of bilateral FDI stocks of twelve old EU member states in ten CEECs to analyse which factors determine FDI. Our findings indicate a rapid adjustment of the FDI stock towards its equilibrium. With respect to the equilibrium FDI stock, the traditional variables are found to be fairly stable determinants. Market potential and trade integration with the source country are positively related to the equilibrium FDI stock. Higher relative unit labour costs vis-a-vis the source country are associated with a lower equilibrium level of foreign investment. Lower perceived riskiness is associated with more FDI. In the case of transition countries perceived riskiness to a large extent reflects progress in institutional 
development. We also find that progress in almost all reform areas, as measured by the EBRD liberalization indicators, is associated with a better FDI record. Non-banking reform is the only exception. The relationship between FDI and privatization is investigated in detail. Our results suggest that current direct privatization has an immediate concurrent positive effect on the equilibrium level of FDI, whereas non-direct privatization schemes slow down adjustment to the equilibrium. Finally, privatization history positively affects the equilibrium level independently of the method applied. 


\section{References}

Arellano, M. and Bond, S. (1991). 'Some tests of specification for panel data: Monte Carlo evidence and an application to employment equations', Review of Economic Studies, vol. 58, pp. 277-98.

Baldwin, R., François, J. and Portes, R. (1997). 'The cost and benefits of Eastern enlargement: The impact on the EU and Central Europe', Economic Policy, vol. 12(24), pp. $125-76$.

Bevan, A. and Estrin, S. (2000). 'The determinants of foreign direct investment in transition economies', CEPR Discussion Paper No. 2638.

Bevan, A., Estrin, S. and Meyer, K. (2004). 'Foreign investment location and institutional development in transition economies', International Business Review, vol. 13, pp. 43-64.

Blundell, R. and Bond, S. (1998). 'Initial conditions and moment restrictions in dynamic panel data models', Journal of Econometrics, vol. 68, pp. 29-52.

Blundell, R. and Bond, S. (1999). 'GMM estimation with persistent panel data: an application to production functions', Institute for Fiscal Studies Working Paper W/99/4.

Carstensen, K. and Toubal, F. (2003). 'Foreign direct investment in Central and Eastern European economies: a dynamic panel data analysis', Journal of Comparative Economics, vol. 32(1), pp. 3-22.

Chakrabarti, A. (2001). 'The determinants of Foreign Direct Investment: Sensitivity Analysis of Cross-Country Regressions', Kyklos, vol. 54, pp. 89-114.

Cheng, L. and Kwan, Y. (2000). 'What are the Determinants of the Location of Foreign Direct Investment? The Chinese Experience', Journal of International Economics, vol. 51, pp. 379-400.

European Bank for Reconstruction and Development, Transition Report, London: EBRD, various issues.

Euromoney Magazine, London, various issues.

Eurostat (2002). European Union foreign direct investment yearbook 2001.

Filatotchev, I., Wright, M., and Bleaney, M. (1999). 'Privatization, Insider Control and Managerial Entrenchment in Russia', Economics of Transition, vol. 7(2), pp. 481-504.

Frydman, R., Gray, C., Hessel, M. and Rapaczynski, A. (1999). 'When Does Privatization Work? The Impact of Private Ownership on Corporate Performance in the Transition Economies', Quarterly Journal of Economics, vol. 114(4), pp. 1153-91.

Garibaldi, P., Mora, N., Sahay, R. and Zettelmeyer, J. (2001). 'What moves capital to transition economies', IMF Staff Papers, vol. 48, pp. 109-45. 
Holland, D. and Pain, N. (1998). 'The diffusion of innovations in Central and Eastern Europe: A study of the determinants and impact of foreign direct investment', National Institute of Economic and Social Research Discussion Paper No. 173.

International Labour Office, 'Handbook of Labour Statistics', Geneva, various issues.

Kinoshita, Y. and Campos, N. (2003). 'Why does FDI go where it goes? New evidence from the transition countries', William Davidson Institute Working Paper No. 573.

Markusen, J. (1995). 'The boundaries of multinational enterprises, and the theory of international trade', Journal of Economic Perspectives, vol. 9(2), pp. 169-89.

Markusen, J. and Maskus, K. (2001). 'General-equilibrium approaches to the multinational firm: A review of theory and evidence', NBER Working Paper No. 8334.

Nickell, S. (1981). 'Biases in dynamic models with fixed effects', Econometrica, vol. 49(6), pp.1417-26.

OECD (2001). 'International Direct Investment Statistics Yearbook: 1980-2000 - Edition 2001', Paris.

Resmini, L. (2000). 'The determinants of foreign direct investment in the CEECs - New evidence from sectoral patterns', Economics of Transition, vol. 8(3), pp. 665-89.

State Audit Office Hungary (2001). 'Privatisation in Hungary 1990-2000', presented to the INTOSAI Working Group on the Audit of Privatisation, Budapest, June.

Windmeijer, F. (2000). 'A finite sample correction for the variance of two-step GMM estimators', Institute for Fiscal Studies Working Paper W/00/19. 


\section{DAVIDSON INSTITUTE WORKING PAPER SERIES - Most Recent Papers}

The entire Working Paper Series may be downloaded free of charge at: www.wdi.bus.umich.edu

CURRENT AS OF 8/10/05

\begin{tabular}{|c|c|c|}
\hline Publication & Authors & Date \\
\hline $\begin{array}{l}\text { No. 785: How to Catch Foreign Fish? FDI and Privatization in EU } \\
\text { Accession Countries }\end{array}$ & $\begin{array}{l}\text { Bruno Merlevede, and Koen } \\
\text { Schoors }\end{array}$ & Aug. 2005 \\
\hline $\begin{array}{l}\text { No. 784: Does the World Bank have any impact on human development } \\
\text { of the poorest countries? Some preliminary evidence from Africa }\end{array}$ & Sumon Kumar Bhaumik & Aug. 2005 \\
\hline $\begin{array}{l}\text { No. 783: Comparative social capital: Networks of entrepreneurs and } \\
\text { investors in China and Russia }\end{array}$ & Bat Batjargal & July 2005 \\
\hline $\begin{array}{l}\text { No. 782: Exchange Rate Regimes, Foreign Exchange Volatility and } \\
\text { Export Performance in Central and Eastern Europe: Just Another Blur } \\
\text { Project? }\end{array}$ & $\begin{array}{l}\text { Balázs Égert and Amalia } \\
\text { Morales-Zumaquero }\end{array}$ & July 2005 \\
\hline $\begin{array}{l}\text { No. 781: Equilibrium Exchange Rate in the Czech Republic: How Good } \\
\text { is the Czech BEER? }\end{array}$ & Ian Babetskii and Balázs Égert & July 2005 \\
\hline $\begin{array}{l}\text { No. 780: Autonomy and Performance of Foreign Subsidiaries in five } \\
\text { Transition Countries }\end{array}$ & $\begin{array}{l}\text { Urmas Varblane, Katrin Männik, } \\
\text { and Helena Hannula }\end{array}$ & July 2005 \\
\hline $\begin{array}{l}\text { No. 779: The Political Economy of Industrial Policy in China: The Case } \\
\text { of Aircraft Manufacturing }\end{array}$ & Andrea Goldstein & July 2005 \\
\hline $\begin{array}{l}\text { No. 778: Bank Supervision Russian style: Rules versus Enforcement } \\
\text { and Tacit Objectives }\end{array}$ & $\begin{array}{l}\text { Sophie Claeys, Gleb Lanine and } \\
\text { Koen Schoors }\end{array}$ & June 2005 \\
\hline No. 777: Labor Market Trends and Institutions in Belarus & $\begin{array}{l}\text { Zuzana Brixiova and Vera } \\
\text { Volchok }\end{array}$ & June 2005 \\
\hline $\begin{array}{l}\text { No. 776: Can Vietnam Achieve One of its Millennium Development } \\
\text { Goals? An analysis of schooling dropouts of children }\end{array}$ & $\begin{array}{l}\text { Vo Tri Thanh And Trinh Quang } \\
\text { Long }\end{array}$ & June 2005 \\
\hline $\begin{array}{l}\text { No. 775: Is The Link Between Reforms And Growth Spurious? A } \\
\text { Comment }\end{array}$ & Tomasz Mickiewicz & May 2005 \\
\hline $\begin{array}{l}\text { No. 774: The Risk Aversion of Banks in Emerging Credit markets: } \\
\text { Evidence from India }\end{array}$ & $\begin{array}{l}\text { Sumon Kumar Bhaumik and } \\
\text { Jenifer Piesse }\end{array}$ & May 2005 \\
\hline $\begin{array}{l}\text { No. 773: Organized Labor and Restructuring: Coal Mines in the Czech } \\
\text { Republic and Romania }\end{array}$ & $\begin{array}{l}\text { Jan Bruha, Delia Ionascu, and } \\
\text { Byeongju Jeong }\end{array}$ & May 2005 \\
\hline $\begin{array}{l}\text { No. 772: Is Political Risk Company-Specific? The Market Side of the } \\
\text { Yukos Affair }\end{array}$ & $\begin{array}{l}\text { Alexei Goriaev and Konstantin } \\
\text { Sonin }\end{array}$ & May 2005 \\
\hline $\begin{array}{l}\text { No. 771: Non-Linear Exchange Rate Dynamics in Target Zones: A } \\
\text { Bumpy Road Towards A Honeymoon }\end{array}$ & $\begin{array}{l}\text { Jesús Crespo-Cuaresma, Balázs } \\
\text { Égert, and Ronald MacDonald }\end{array}$ & May 2005 \\
\hline $\begin{array}{l}\text { No. 770: Equilibrium Exchange Rates in Southeastern Europe, Russia, } \\
\text { Ukraine and Turkey: Healthy or (Dutch) Diseased? }\end{array}$ & Balázs Égert & May 2005 \\
\hline $\begin{array}{l}\text { No. 769: Equilibrium Exchange Rates in Central and Eastern Europe: A } \\
\text { Meta-Regression Analysis }\end{array}$ & Balázs Égert and László Halpern & May 2005 \\
\hline $\begin{array}{l}\text { No. 768: Testing for inflation convergence between the Euro Zone } \\
\text { and its CEE partners }\end{array}$ & Imed Drine and Christophe Rault & Apr. 2005 \\
\hline $\begin{array}{l}\text { No. 767: Labor Mobility during Transition: Evidence from the Czech } \\
\text { Republic }\end{array}$ & Jan Fidrmuc & Apr. 2005 \\
\hline $\begin{array}{l}\text { No. 766: Formation of social capital in Central and Eastern Europe: } \\
\text { Understanding the gap vis-à-vis developed countries }\end{array}$ & Jan Fidrmuc and Klarita Gërxhani & Apr. 2005 \\
\hline $\begin{array}{l}\text { No. 765: Do Regional Integration Agreements Increase Business-Cycle } \\
\text { Convergence? Evidence From APEC and NAFTA }\end{array}$ & $\begin{array}{l}\text { Viviana Fernandez and Ali M. } \\
\text { Kutan }\end{array}$ & Apr. 2005 \\
\hline $\begin{array}{l}\text { No. 764: State Regulations, Job Search and Wage Bargaining: A Study } \\
\text { in the Economics of the Informal Sector }\end{array}$ & Maxim Bouev & Apr. 2005 \\
\hline $\begin{array}{l}\text { No. 763: The Feldstein-Horioka Puzzle Revisited: An “European- } \\
\text { Regional” Perspective }\end{array}$ & $\begin{array}{l}\text { Jérôme Hericourt and Mathilde } \\
\text { Maurel }\end{array}$ & Apr. 2005 \\
\hline $\begin{array}{l}\text { No. 762: Transatlantic Differences in Labour Markets Changes in Wage } \\
\text { and Non-Employment Structures in the 1980s and the 1990s }\end{array}$ & Patrick A. Puhani & Mar. 2005 \\
\hline $\begin{array}{l}\text { No. 761: Resolution, Recovery and Survival: The Evolution of Payment } \\
\text { Disputes in Post-Socialist Europe }\end{array}$ & William Pyle & Mar. 2005 \\
\hline $\begin{array}{l}\text { No. 760: Official Foreign Exchange Interventions in the Czech } \\
\text { Republic: Did They Matter? }\end{array}$ & Balázs Égert and Luboš Komárek & Mar. 2005 \\
\hline
\end{tabular}

